\title{
СИНТЕЗ И СВОЙСТВА 1,3-ДИЗАМЕЩЕННЫХ МОЧЕВИН С ВЫСОКОЛИПОФИЛЬНОЙ ГРУППОЙ ПРИРОДНОГО ПРОИСХОЖДЕНИЯ
}

\author{
Д.А. Питушкин, М.Х. Саиф Аббас, В.В. Бурмистров, Г.М. Бутов
}

Кафедра химии, технологии и оборудования химических производств ВПИ (филиал) Волгоградский государственный технический университет, 404131, Россия, г. Волжский, ул. Энгельса, 42а.

DOI: 10.19163/MedChemRussia2021-2021-69

E-mail: kartes07@mail.ru

В работе представлены исследования по созданию новых высокоактивных ингибиторов уреидного типа для растворимой эпоксидгидролазы (sEH), в структуре которых присутствуют фрагменты природного происхождения. В структуре известных ингибиторов липофильный адамантильный радикал $\mathrm{R}_{1}$ был заменен на бициклические природные фрагменты, а радикал $R_{2}$ содержал производные пиримидина и пурина.

Разработаны способы синтеза 1,3-дизамещенных мочевин по реакции аминов с изоцианатами, которые содержали бициклические заместители. Разработан способ получения изоцианатов, содержащих фрагменты природного происхождения.

Разработаны one-pot методы синтеза симметричных и несимметричных мочевин в трехкомпонентных реакциях аминов с карбонилдиимидазолом. Показано влияние основности амина на выход несимметричной мочевины, при изменении порядка загрузки реагентов.<smiles>[R]NC(=O)NC</smiles>

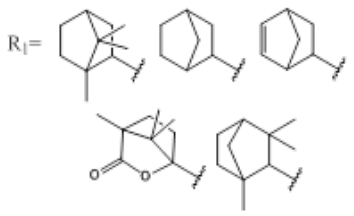

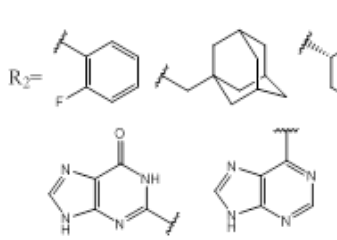

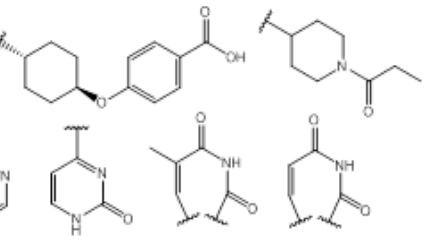

Исследована ингибирующая активность полученных мочевин в отношении sEH. Установлено, что введение фрагмента природного происхождения увеличивает растворимость ингибитора в воде, при сохранении активности на высоком уровне.

Работа выполнена при финансовой поддержке Российского фонда

фундаментальных исследований (грант № 19-33-60024 Перспектива). 